Maciej Jędrusik

\title{
SOCIAL ISOLATION AS A GEOGRAPHICAL PHENOMENON
}

To avoid any possible confusion about the term isolation and to understand this word from a geographical point of view, we shall specify its context and re-phrase it as spatial isolation. Isolation results in the separation and division of population groups. It is therefore meaningful to consider what causes the spatial isolation of these groups. The most likely explanation for this occurrence is limited accessibility to those regions. This can be caused by geographical remoteness (distance) coupled with existing natural barriers.

\section{ISOLATED REGIONS}

What regions of the globe are the most difficult to reach? The classical example of a region with limited accessibility are islands. It is interesting to note that in many European languages, the word island is closely related to the word isolation, beginning with the Latin insula, the Italian isola and going on to the French ile, the Spanish isla, the German Insel and of course the English word island. Over the past years, the study of islands and insularity has evolved especially in France (Gourou P., Doumenge F., Doumenge J.P., Singaravelou, Saussol A., Huetz de Lemps Ch., Huetz de Lemps A. and others). Pierre George in Dictionnaire de la géographie, defines an island as a piece of land isolated from all sides by water. It is interesting to note that he uses the word isolated - and not surrounded, or encircled (Lasserre, 1987).

The contact between an island and a continent is made difficult by water. Water is a barrier, and intuitively we can accept that the larger the distance from the continent, the more difficult it is to reach the island, and thus the isolation of an island situated further is greater. However, this is only partly confirmed by observations of plant and animal distribution (MacArthur, Wilson, 1967; Doumenge F., 1984, 1987). This leads to the conclusion that geographical distance or remoteness, is not the only factor that determines the degree of regional isolation. Biologists often treat regions with differing characteristics to their surroundings as "islands". These can include small wooded areas in between meadows, glades in forests and green areas in 
cities. Separation causes endemism. It is tempting for sociologists to extend this theory to groups of people as well. Some forms of habitation are more adapted to survive in certain specific areas. Thanks to this, it is possible to treat the communities of certain regions as relicts of the past (Bonniol, 1987).

But, does an island have to be surrounded by water to be considered an island? Many characteristics attributed solely to land masses can be found on continents, especially in country - enclaves (e.g. Bhutan) and oases. The barrier here, the equivalent of water, is the desert. Another example of "continental" islands can be mid-mountain valleys and plateaus, to which access is often barred or made difficult by high mountain ridges. The geographical distance - "as the crow flies" - may actually be quite small, however, neighbouring communities will still develop independently of each other. The barrier here, are the slopes with an extremely steep gradient.

Settlements that are situated deeply forests or surrounded by marshlands can also be considered as examples of "continental islands".

The very existence of isolation carries with it certain effects. It can be assumed, that a similar degree of isolation results in similar effects in the functioning of communities inhabiting a given region.

That is why it is not important, whether the studied area is an island, an oasis, a plateau, a mid-mountain valley or a forest settlement. The communities that inhabit these areas, can function in a similar fashion as a result of the existence of spatial isolation.

The degree of this isolation alters with time. With this alteration, the functioning characteristics of the isolated area also change.

\section{MEASUREMENT OF SPATIAL ISOLATION}

Spatial isolation is difficult to measure. Can it even be measured? How can one distinguish which region is more isolated than another? It is difficult to find an objective scale that is expressed in absolute units. The concepts of isolation and distance are not synonymous. Distance is thus only one, and not necessarily even the most important, characteristic of isolation.

It was claimed earlier that the closest literal meaning of spatial isolation is the concept of seclusion. It is thus necessary to consider what characteristics determine the extent of the seclusion of a region.

Seclusion is associated with difficult access to information. Today, with the process of globalisation well under way, there are continuously less and less information barriers throughout the world. It can be assumed that television, radio, the telephone, or computer networks and the internet are becoming more and more accessible and it is difficult to find examples of places on earth where these goods are unknown. Therefore, in the rest of the study these methods of information exchange shall be disregarded. There exist differences between the physical accessibility of humans to var- 
ious areas throughout the world. Thus, when searching for characteristics of spatial isolation, it is necessary to concentrate on the elements that decide the amount of outside human contact with the studied region, because Man is the carrier of information.

Along with the increase in the number of contacts, the amount of information reaching the region also rises. With this information, there is a decrease in isolation. The number of contacts is not a characteristic of isolation, but it can be used as one of its methods of measurement. One can imagine an island that is situated near the mainland, contains a harbour, an airport and a number of hotels, and has an attractive environment but still remains unvisited due to - for instance - the reign of tyrant ${ }^{1}$. The lack of contact determines the degree of isolation of its community.

Therefore, as far as the above mentioned environmental, emotional and infrastructure elements can be used as a measure of the isolation of a region, then the frequency of contacts becomes a measure of isolation of communities living in the area.

A different scale has to be adopted to determine the isolation of communities living in a given region. The lower the frequency of contacts of such communities with the outside world, the higher the level of isolation.

Eight different scales of isolation separated into three groups have been proposed. In the first group - that of the natural influences are:

1.a. - the separation from source regions;

1.b. - the location in a group, an archipelago or near the edge of a continent;

1.c. - accessibility throughout the year.

In the second group - the technical infrastructure of a region - the following were named as different measures:

2.a. - Elements of the infrastructure according to groups from the following table:

\begin{tabular}{|c|l|l|l|}
\hline Group & \multicolumn{1}{|c|}{ Islands } & \multicolumn{1}{|c|}{ Oases } & \multicolumn{1}{|c|}{ Plateaus/Valleys } \\
\hline 5 & International airport & International airport & \\
4 & Regional airport, bridge & $\begin{array}{l}\text { Regional airport } \\
\text { Bus station, local airport, } \\
\text { train station }\end{array}$ & Deep water Harbour \\
3 & $\begin{array}{l}\text { Taxi stop, landing strip } \\
\text { Yacht quay, ferry }\end{array}$ & $\begin{array}{l}\text { Railway line, taxi stop, } \\
\text { landing strip }\end{array}$ \\
1 & Landing, local airport & & \\
\hline
\end{tabular}

2.b. - hotel accommodation;

2.c. - restaurants;

2.d. - the frequency of transport connections (the type of transport does not play a role here - what is important is that some sort of mass transit exists).

\footnotetext{
${ }^{1}$ Can, for example, North Korea be considered as such an "island"?
} 
In the third group - the attractiveness of the region. The scales of measurement are:

3.a. - tourist attractions including: environment, history and culture as well as strategic and trade advantages, as well as natural resources; 3.b. - the population size.

Each of measurement scales was given a value, according to its alleged importance in causing the isolation phenomenon. The following criteria were used as guidelines:

I. Individual groups of elements are equally important for the occurrence of isolation. That is why each potential group should obtain a similar maximum value (around 30 points).

II. Some of the elements seem to be more important than others. The most important elements seem to be the distance from source regions, hotel accommodation, tourist attractions and the technical infrastructure. These scales of measurement should thus take on the highest and similar values.

The joint sum for all the groups can attain 90 points $^{2}$. The sum of all the indicators from each group for every one of the studied regions determines its degree of isolation.

However, the degree of isolation of communities inhabiting the isolated region, is measured by the frequency of contacts of the community with the outside world. The most suitable measure seems to be the coefficient $i$, that describes the relationship between the number of outside visitors per year to the population of the region. The smaller the value of the coefficient, then the smaller the interference of the outside world in the functioning of the community.

Thus the scale of measure of spatial isolation in the studied area shall be determined by combining two values: the degree of isolation of the region and the degree of isolation of the region's community.

\section{THE STUDIED AREAS}

Thirty three isolated areas - situated on islands, in oases and in mountainous or hilly regions - were considered. Each particular example represents a different location in terms of the source regions and the various degrees of "openness" of the community to the outside world. The following areas belong to the studied group: the islands of Micronesia (Jap, Mili, Ebon, Nukuoro ${ }^{3}$ ), the Andaman Sea (Panyi, Phuket, Phi Phi, Lanta), the Gulf of

\footnotetext{
${ }^{2}$ It is possible for a group to attain slightly more points. This is due to an undefined number of objects in the technical infrastructure.

${ }^{3}$ In the case of the Jap and Nukuoro islands, a comparison was carried out between their states of isolation in the middle of the $19^{\text {th }}$ and at the end of the $20^{\text {th }}$ century.
} 
Thailand (Samet, Chang, Samui, Tao, Pha-Ngan), the Seychelles (Praslin, Silhouette, Desroches), the Cyclades and the Dodecanese (Astipalea, Thira, Sifnos, Amorgos), isolated hilly and mountainous regions (Shimshal in Caracorum, Causse Noir in the southern Cévennes, Cirque de Cilaos and Cirque de Mafate on the island of Réunion, Cerdanya in the Eastern Pyrenees) as well as oases (Farafra in Egypt and Tamers, Zaafrane, Douz, Gabès, Tozeur in Tunisia).

\section{SIMILARITIES AND DIFFERENCES.}

The grouping of the studied regions

The analysis of the above mentioned 33 cases of isolated regions, their natural elements, their technical infrastructure as well as a rating of their attractiveness has made it possible to assign each region the following mark:

\begin{tabular}{|c|c|c|c|c|c|c|}
\hline 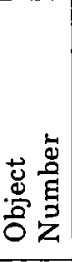 & 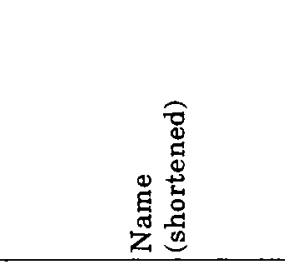 & 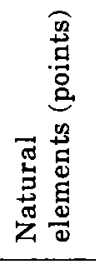 & 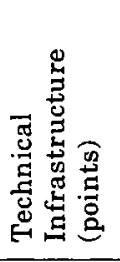 & 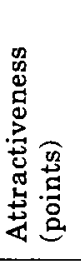 & 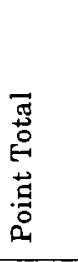 & 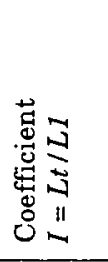 \\
\hline 1. & Koh Panyi (Pyi) & 21 & 10 & 12 & 43 & 270 \\
\hline 2. & Koh Phuket (Phu) & 21 & 29 & 20 & 70 & 8.7 \\
\hline 3. & Koh Phi Phi (Phi) & 19 & 14 & 12 & 45 & 270 \\
\hline 4. & Koh Lanta (Lan) & 16.5 & 12 & 11 & 39.5 & 2.8 \\
\hline 5. & Koh Samet (Smt) & 18 & 14 & 11 & 43 & 250 \\
\hline 6. & Koh Chang (Cha) & 12 & 15 & 11 & 38 & 6 \\
\hline 7. & Koh Samui (Smi) & 18 & 27 & 19 & 64 & 29 \\
\hline 8. & Koh Pha-Ngan (Phg) & 9 & 16 & 10 & 35 & 12 \\
\hline 9. & Koh Tao (Tao) & 10.8 & 8 & 8 & 26.8 & 67 \\
\hline 10. & Jap 19 (J19) & 6 & 7 & 12 & 25 & 0.02 \\
\hline 11 & Jap $20(\mathrm{~J} 20)$ & 9 & 13 & 11 & 33 & 0.8 \\
\hline 12. & Mili (Mil) & 6 & 9 & 8 & 23 & 0.4 \\
\hline 13. & Nukuoro 19 (N19) & 3 & 5 & 6 & 14 & 0.4 \\
\hline 14. & Nukuoro 20 (N20) & 3 & 9 & 6 & 18 & 2 \\
\hline 15. & Ebon (Ebo) & 3 & 5 & 7 & 15 & 0.1 \\
\hline 16. & Zaafrane (Zaa) & 18 & 12 & 7 & 37 & 20 \\
\hline 17. & Desroches (Des) & 3 & 10 & 7 & 20 & 29 \\
\hline 18. & Tamerza (Tam) & 22 & 12 & 9 & 43 & 20 \\
\hline 19. & Silhouette (Sil) & 13 & 6 & 8 & 27 & 8 \\
\hline 20. & Cerdanya (Cer) & 30 & 21 & 16 & 67 & 12 \\
\hline 21. & Praslin (Pra) & 12 & 16 & 13 & 41 & 26 \\
\hline 22. & Cilaos (Cil) & 12 & 17 & 15 & 44 & 17 \\
\hline 23. & Causse Noir (CNr) & 16.5 & 9 & 11 & 36.5 & 370 \\
\hline
\end{tabular}




\begin{tabular}{|c|c|c|c|c|c|c|}
\hline 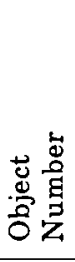 & 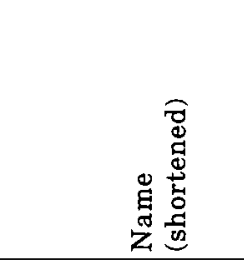 & 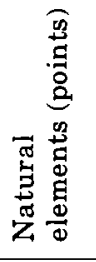 & 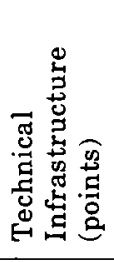 & 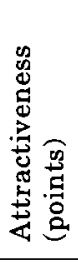 & 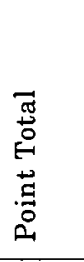 & 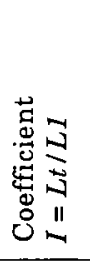 \\
\hline 24. & Mafate (Maf) & 7.8 & 5 & 8 & 20.8 & 13 \\
\hline 25. & Shimshal (Shi) & 3 & 3 & 7 & 13 & 0 \\
\hline 26. & Douz (Dou) & 18 & 14 & 12 & 44 & 4.2 \\
\hline 27. & Gabès (Gab) & 24 & 21 & 18 & 63 & 5.6 \\
\hline 28. & Farafra (Far) & 10.8 & 11 & 10 & 31.8 & 3.4 \\
\hline 29. & Folegandros (Fol) & 18 & 10 & 10 & 38 & 36 \\
\hline 30. & Amorgos (Amo) & 18 & 15 & 12 & 45 & 1.8 \\
\hline 31. & Astipalea (Ast) & 9 & 14 & 8 & 31 & 4.7 \\
\hline 32. & Thira (Thi) & 15 & 25 & 19 & 59 & 32 \\
\hline 33. & Rodrigues (Rod) & 9 & 11 & 9 & 29 & 0.4 \\
\hline
\end{tabular}

Source: Self Researched.

Thus it can be safely said that the highest degree of spatial isolation occurs in the Nukuoro and Ebon atolls as well as on the Shimshal plateau. The most "open" regions are three islands (Phuket, Samui and Thira), an oasis (Gabès) and a valley (Cerdanya). In the remaining groups it is also possible to come across examples of different types of regions: group 2-6 islands, 1 mountainous region; group 3-5 islands, 2 oases, 1 plateau; group 4-6 islands, 2 oases, 1 mountainous region.

The range of the values $i$, (the quotient of newcomers from outside $(L t)$ to the number of inhabitants $(L 1)$ ) is indeed very large, from 0 (Shimshal) to 370 (Causse Noir). It is important to remember, however, that it is difficult to estimate the number of newcomers to many regions, and that official statistics are carried out only sporadically. Each of the studied regions were given to values $I p$ and $I$. This makes it possible to place the object in a plane of coordinates, where the $\mathrm{x}$-axis represents the spatial isolation and the $y$-axis, the social isolation.

Comparing the distances allows us to use the following equation:

$$
D+\sqrt{ }\left((I p j-I p i)^{2}+(i i-i i)^{2}\right)
$$

where:

$D$ - is the distance,

$I p j$ - is the spatial isolation at point $j$,

$I p i$ - is the spatial isolation at point $i$,

$i j-$ is the coefficient of social isolation at point $j$,

ii - is the coefficient of social isolation at point $i$.

As a result of this typological procedure, that included spatial and social values of isolation from each of the regions, it became clear that each of the 33 studied cases can be divided into six groups. 


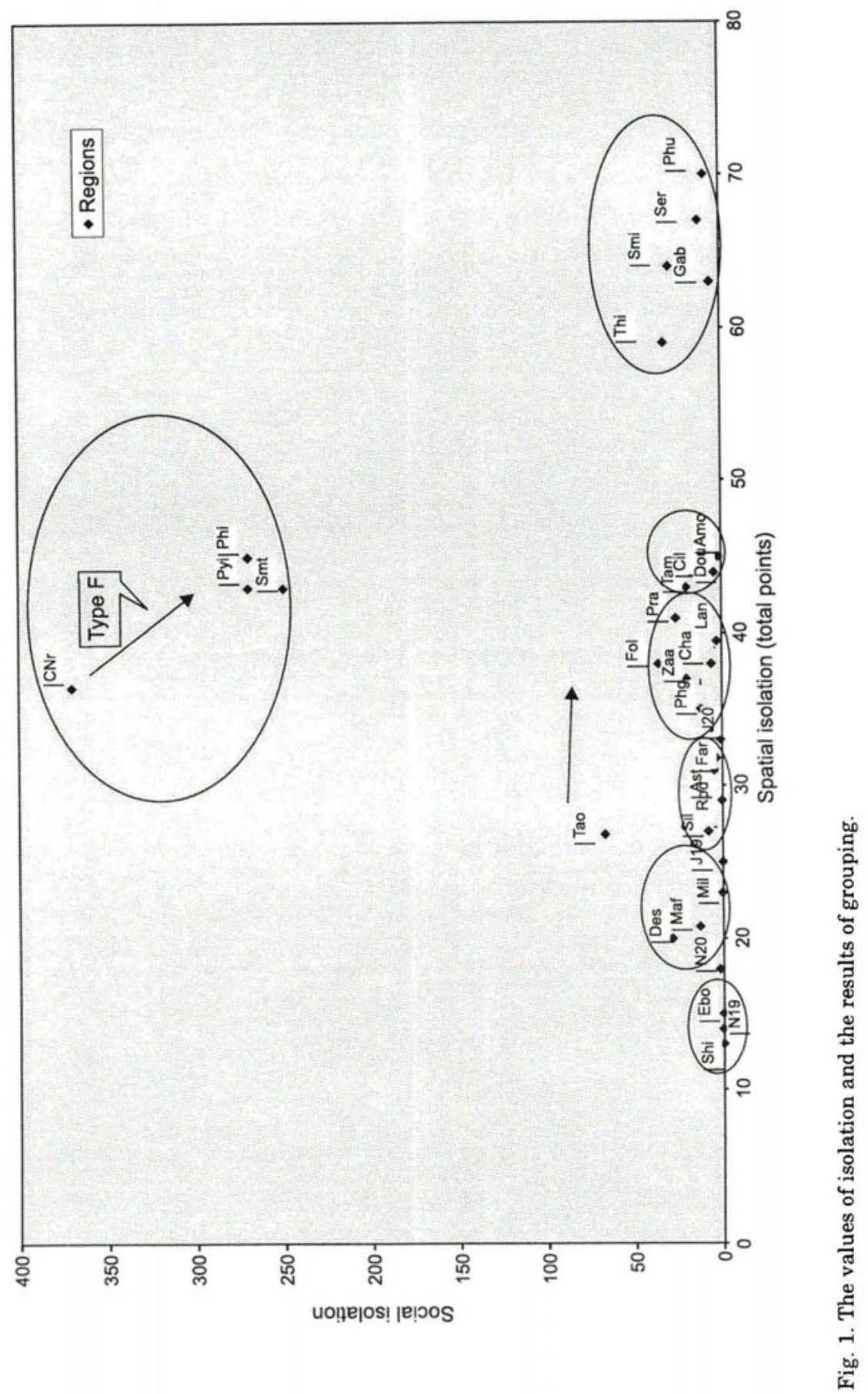




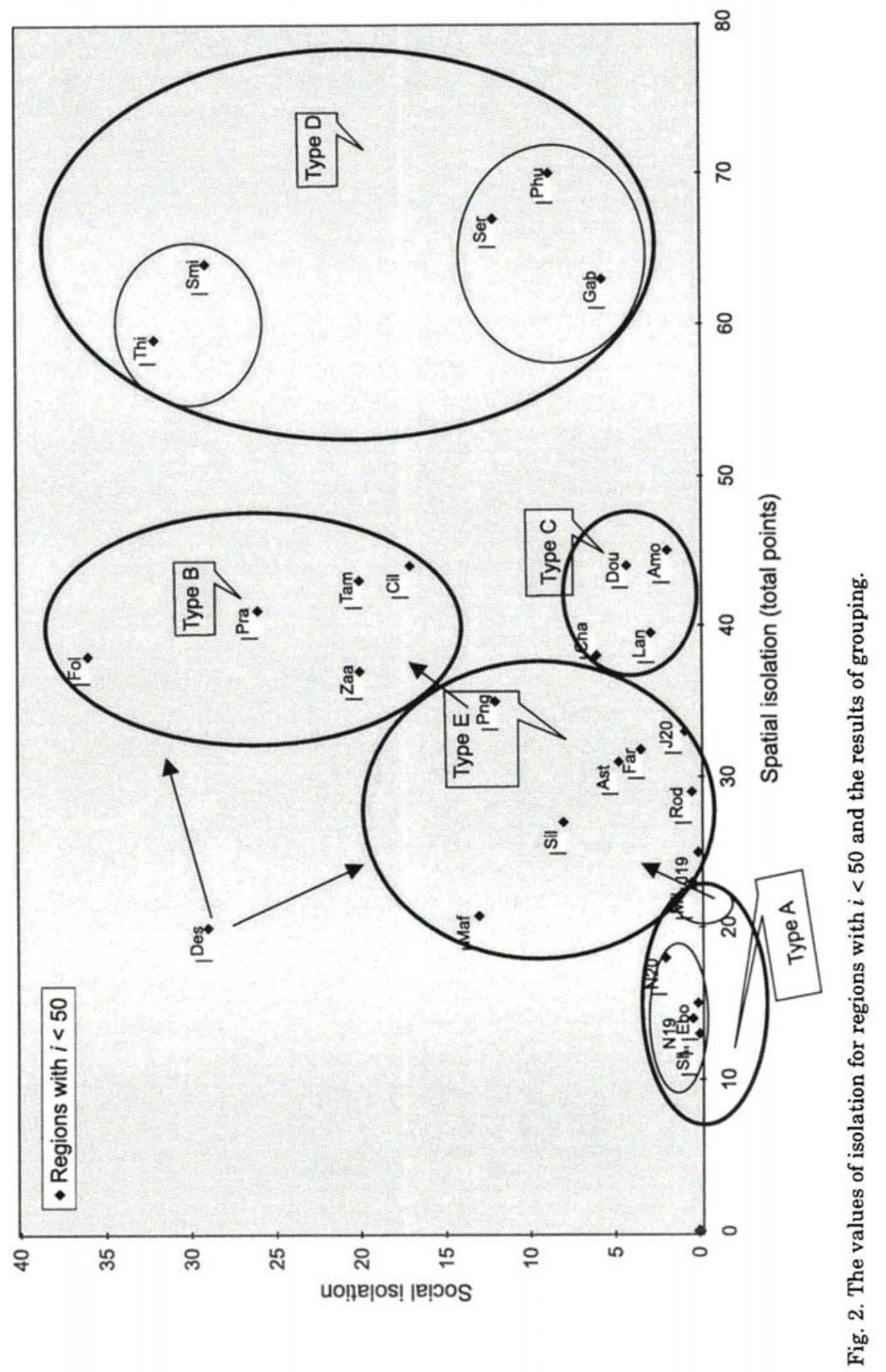




\begin{tabular}{|l|l|l|l|l|l|}
\hline \multicolumn{1}{|c|}{ Type A } & \multicolumn{1}{|c|}{ Type B } & \multicolumn{1}{c|}{ Type C } & \multicolumn{1}{c|}{ Type D } & \multicolumn{1}{c|}{ Type E } & \multicolumn{1}{c|}{ Type F } \\
\hline Shimshal & Praslin & Lanta & Cerdanya & Rodrigues & Samet \\
Nuk. $\left(19^{\text {th }}\right.$ c.) & Zaafrane & Chang & Phuket & Jap $\left(20^{\text {th }}\right.$ c.) & Phi Phi \\
Nuk. $\left(20^{\text {th }}\right.$ c.) & Tamerza & Douz & Gabès & Farafra & Panyi \\
Ebon & Cilaos & Amorgos & & Astipalea & \\
Mili & Folegandros & & (Thira) & $\begin{array}{l}\text { Silhouette } \\
\text { Mafate } \\
\text { Jap (19 }\end{array}$ & (Samui) \\
& (Tao) & & & $\begin{array}{l}\text { (C.Noir) } \\
\text { (Desroches) }\end{array}$ & \\
\hline
\end{tabular}

The above table shows the obtained grouping. Each of groups can be defined in the following way:

A - regions with a high spatial and social isolation. The number of visitors from outside is very small both in absolute terms as well as a percentage of the population.

B - regions that are not very spatially isolated. Places that are readily visited by outsiders who annually outnumber the population several times.

$\mathrm{C}$ - regions that are not very spatially isolated. Places that are rarely visited by outsiders who annually outnumber the population a dozen times or so.

D - regions that are relatively "open" to visitors, both from a spatial and from a social point of view; the number of newcomers from outside outnumber the population either several (in the case of heavily populated regions) or several dozen times.

$\mathrm{E}$ - regions that have a high spatial isolation, and few thus visits by outsiders (except for Desroches, the number of visitors is a couple of times higher than the number of inhabitants of the region).

$\mathrm{F}$ - regions that are not spatially isolated, visited annually by a very large number of "outsiders".

\section{THE CHARACTERSITICS OF COMMUNITIES AND THE DEGREE OF THEIR ISOLATION}

When studying this relationship is important to take notice of those characteristics that could change due to contact with the outside world. These can be divided into three groups: social characteristics, economic characteristics as well as characteristics that describe the spatial organisation within the studied region (from now on these shall be termed as spatial characteristics). Thus the characteristics are:

I. Social characteristics (A. population density, B. the type and the size of migration, C. religious structure, D. ethnic structure)

II. Economic characteristics (E. the degree of economic modernisation, F. the role played by tourism in the regional economy, $\mathrm{G}$. the contribution of the tertiary sector (services) to the regional economy, $\mathrm{H}$. new phenomena in the regional economy) 
III. Spatial characteristics (I. the settlement pattern, J. the type of zoning of the area, $K$. the degree of development of the technical infrastructure, $\mathrm{L}$. the degree of development of the social infrastructure).

It has been accepted by convention that, the value of each of the characteristics can be expressed on a scale of 1 to 5 , and higher values point to beneficial occurrences, that is those favouring transformation for the community of the region. Below are the values for each of the characteristics:

\begin{tabular}{|c|c|c|c|}
\hline Group & Characteristic & Value & Description \\
\hline \multirow[t]{11}{*}{ I } & A & $\begin{array}{l}5 \\
4 \\
3 \\
2 \\
1\end{array}$ & $\begin{array}{l}500 \text { and more inhabitants per } \mathrm{km}^{2} \\
100-499 \text { inhabitants per } \mathrm{km}^{2} \\
50-99 \text { inhabitants per } \mathrm{km}^{2} \\
20-49 \text { inhabitants per } \mathrm{km}^{2} \\
\text { Below } 20 \text { inhabitants per } \mathrm{km}^{2}\end{array}$ \\
\hline & B & $\begin{array}{l}5 \\
4 \\
3 \\
2 \\
1\end{array}$ & $\begin{array}{l}\text { High immigration, emigration negligible } \\
\text { A higher degree of immigration than emigration } \\
\text { A balance between emigration and immigration, no } \\
\text { significant migration occurs here } \\
\text { A higher degree of emigration than immigration } \\
\text { High emigration, immigration negligible }\end{array}$ \\
\hline & $\mathrm{C}$ & 5 & $\begin{array}{l}\text { Complete dominance of a single faith (the percentage of } \\
\text { the population of a different faith does not exceed 10\%) } \\
\text { Dominance of a single faith (the percentage of the } \\
\text { population of the second faith does not exceed } 33 \% \text { and } \\
\text { other faiths do not exceed } 5 \% \text { of the population) }\end{array}$ \\
\hline & & 3 & $\begin{array}{l}\text { Two faiths present (the percentage of the population of } \\
\text { the second faith forms more than } 33 \% \text { and the other } \\
\text { faiths do not exceed } 5 \% \text { of the total) }\end{array}$ \\
\hline & & 2 & $\begin{array}{l}\text { Three (or more) faiths present, one of these dominate } \\
\text { (the adherents make up more than } 50 \% \text { of the } \\
\text { population) }\end{array}$ \\
\hline & & 1 & $\begin{array}{l}\text { Three (or more) faiths present, none of the adherents of } \\
\text { the individual faiths make up more than } 50 \% \text { of the } \\
\text { population }\end{array}$ \\
\hline & $\mathrm{D}$ & 5 & $\begin{array}{l}\text { Complete dominance by a single ethnic group (the } \\
\text { percentage of the other does not exceed } 10 \% \text { of the } \\
\text { population) }\end{array}$ \\
\hline & & 4 & $\begin{array}{l}\text { Dominance of one ethnic group (the second does not } \\
\text { exceed } 33 \% \text { of the population and others do not exceed } \\
5 \% \text { of the population) }\end{array}$ \\
\hline & & 3 & $\begin{array}{l}\text { Two ethnic groups present (the percentage of the } \\
\text { population of the second ethnic group makes up more } \\
\text { than } 33 \% \text { and the other ethnic groups do not exceed } 5 \% \\
\text { of the total) }\end{array}$ \\
\hline & & 2 & $\begin{array}{l}\text { Three (or more) ethnic groups present, one of them } \\
\text { dominates (more than } 50 \% \text { of the population) }\end{array}$ \\
\hline & & 1 & $\begin{array}{l}\text { Three (or more) ethnic groups present, none of which } \\
\text { make up more than } 50 \% \text { of the population }\end{array}$ \\
\hline
\end{tabular}




\begin{tabular}{|c|c|c|c|}
\hline Group & Characteristic & Value & Description \\
\hline \multirow[t]{20}{*}{ II } & \multirow[t]{5}{*}{$\mathrm{E}$} & 5 & Market economy, with a differentiated structure \\
\hline & & 4 & $\begin{array}{l}\text { Mostly a market economy, a modern monoculture sector, } \\
\text { existing characteristics of a traditional economy }\end{array}$ \\
\hline & & 3 & $\begin{array}{l}\text { A transitional economy from a traditional to a market } \\
\text { structure (though none of these dominate yet) }\end{array}$ \\
\hline & & 2 & $\begin{array}{l}\text { Traditional economy with elements from the market } \\
\text { economy }\end{array}$ \\
\hline & & 1 & $\begin{array}{l}\text { Domination of traditional economy, mostly subsistence } \\
\text { production }\end{array}$ \\
\hline & \multirow[t]{5}{*}{$\mathrm{F}$} & 5 & $\begin{array}{l}\text { Hotel accommodation (the number of rooms per } \\
\text { inhabitant multiplied by a hundred) above } 50\end{array}$ \\
\hline & & 4 & $\begin{array}{l}\text { Hotel accommodation (the number of rooms per } \\
\text { inhabitant multiplied by a hundred) } 10,01-50\end{array}$ \\
\hline & & 3 & $\begin{array}{l}\text { Hotel accommodation (the number of rooms per } \\
\text { inhabitant multiplied by a hundred) } 5,01-10\end{array}$ \\
\hline & & 2 & $\begin{array}{l}\text { Hotel accommodation (the number of rooms per } \\
\text { inhabitant multiplied by a hundred) } 1-5\end{array}$ \\
\hline & & 1 & $\begin{array}{l}\text { Hotel accommodation (the number of rooms per } \\
\text { inhabitant multiplied by a hundred) below } 1\end{array}$ \\
\hline & \multirow[t]{5}{*}{ G } & 5 & $\begin{array}{l}\text { The percentage of the economically active population } \\
\text { employed in the service sector exceeds } 50 \% \text {, diversified } \\
\text { services }\end{array}$ \\
\hline & & 4 & $\begin{array}{l}\text { The percentage of the economically active population } \\
\text { employed in the service sector exceeds } 50 \% \text {, one type of } \\
\text { service dominates }\end{array}$ \\
\hline & & 3 & $\begin{array}{l}\text { The percentage of the economically active population } \\
\text { employed in the service sector does not exceed } 50 \% \text {, } \\
\text { diversified services, mostly formal services }\end{array}$ \\
\hline & & 2 & $\begin{array}{l}\text { The percentage of the economically active population } \\
\text { employed in the service sector does not exceed } 50 \% \text {, } \\
\text { mostly in the informal sector }\end{array}$ \\
\hline & & 1 & $\begin{array}{l}\text { The percentage of the economically active population } \\
\text { employed in the service sector does not exceed } 10 \% \text {, } \\
\text { mostly informal services and possibly neighbourly or } \\
\text { community assistance }\end{array}$ \\
\hline & \multirow[t]{5}{*}{$\mathrm{H}$} & 5 & $\begin{array}{l}\text { Substantial new economic investment in various } \\
\text { economic sectors (agriculture, industry, tourism) in the } \\
\text { course of the last five years }\end{array}$ \\
\hline & & 4 & $\begin{array}{l}\text { Small capital investment (including the purchase of land) } \\
\text { by local (national) and external (foreign) capital in the } \\
\text { last five years }\end{array}$ \\
\hline & & 3 & $\begin{array}{l}\text { Small capital investment (including the purchase of land) } \\
\text { by local (national) capital in the last five years }\end{array}$ \\
\hline & & 2 & $\begin{array}{l}\text { Privatisation, increasing of economic intensity in the last } \\
\text { five years }\end{array}$ \\
\hline & & 1 & No noticeable new changes in the economy \\
\hline
\end{tabular}




\begin{tabular}{|c|c|c|c|}
\hline Group & Characteristic & Value & Description \\
\hline \multirow[t]{17}{*}{ III } & \multirow[t]{5}{*}{ I } & 5 & $\begin{array}{l}\text { More than one important settlement, well developed } \\
\text { communication between settlements, many smaller } \\
\text { settlements }\end{array}$ \\
\hline & & 4 & $\begin{array}{l}\text { More than one important settlement, well developed } \\
\text { communication between settlements, low population } \\
\text { density in the rest of the region }\end{array}$ \\
\hline & & 3 & $\begin{array}{l}\text { More than one important settlement, poor communication } \\
\text { between settlements, and (or) low population density in } \\
\text { the rest of the region }\end{array}$ \\
\hline & & 2 & $\begin{array}{l}\text { One larger settlement, a high population density in the } \\
\text { rest of the region, many smaller settlements }\end{array}$ \\
\hline & & 1 & $\begin{array}{l}\text { One larger settlement, low population density in the rest } \\
\text { of the region, not very many smaller settlements }\end{array}$ \\
\hline & \multirow[t]{5}{*}{$J$} & 5 & $\begin{array}{l}\text { Many multi-storey buildings, use of various building } \\
\text { materials }\end{array}$ \\
\hline & & 4 & $\begin{array}{l}\text { Mostly low buildings (only a few storeys), there are a } \\
\text { few multi-storey buildings, use of various building } \\
\text { materials }\end{array}$ \\
\hline & & 3 & $\begin{array}{l}\text { Low buildings dominate (max. a couple of storeys), no } \\
\text { multi-storey buildings, wooden and (or) brick houses }\end{array}$ \\
\hline & & 2 & $\begin{array}{l}\text { 1-2 storey buildings dominate, made of wood or stone (or } \\
\text { other simple building materials such as corrugated iron) }\end{array}$ \\
\hline & & 1 & 1-2 storey houses made of wood dominate \\
\hline & \multirow[t]{5}{*}{ K } & 5 & $\begin{array}{l}\text { At least four of the following objects exist: water-supply } \\
\text { system, sewerage system, electricity grid, tarred roads in } \\
\text { most of the region, a well-functioning mass transit } \\
\text { system }\end{array}$ \\
\hline & & 4 & $\begin{array}{l}\text { At least three of the following objects exist: water- } \\
\text { supply system, sewerage system, electricity grid, tarred } \\
\text { roads in most of the region, a well-functioning mass } \\
\text { transit system }\end{array}$ \\
\hline & & 3 & $\begin{array}{l}\text { At least two of the following objects exist: water-supply } \\
\text { system, sewerage system, electricity grid, tarred roads in } \\
\text { most of the region, a well-functioning mass transit } \\
\text { system }\end{array}$ \\
\hline & & 2 & $\begin{array}{l}\text { At least one of the following objects exist: water-supply } \\
\text { system, sewerage system, electricity grid, tarred roads in } \\
\text { most of the region, a well-functioning mass transit } \\
\text { system }\end{array}$ \\
\hline & & 1 & $\begin{array}{l}\text { None of the following objects exist: water-supply system, } \\
\text { sewerage system, electricity grid, tarred roads in most of } \\
\text { the region, a well-functioning mass transit system }\end{array}$ \\
\hline & \multirow[t]{2}{*}{$\mathrm{L}$} & 5 & $\begin{array}{l}\text { At least four of the following objects exist: school, health } \\
\text { centre or hospital, post office, bank, cultural centre } \\
\text { (place of public gathering) }\end{array}$ \\
\hline & & 4 & $\begin{array}{l}\text { At least three of the following objects exist: school, } \\
\text { health centre or hospital, post office, bank, cultural } \\
\text { centre (place of public gathering) }\end{array}$ \\
\hline
\end{tabular}




\begin{tabular}{|c|c|c|l|}
\hline Group & Characteristic & Value & \multicolumn{1}{c|}{ Description } \\
\hline & 3 & $\begin{array}{l}\text { At least two of the following objects exist: school, health } \\
\text { centre or hospital, post office, bank, cultural centre } \\
\text { (place of public gathering) } \\
\text { At least one of the following objects exist: school, health } \\
\text { centre or hospital, post office, bank, cultural centre } \\
\text { (place of public gathering) } \\
\text { None of the following objects exist: school, health centre } \\
\text { or hospital, post office, bank, cultural centre (place of } \\
\text { public gathering) }\end{array}$ \\
\hline
\end{tabular}

The functioning of the communities of each of the regions (in terms of the named above geographical characteristics) can be written in, what shall be further referred to as a code, of 12 values between 1 and 5 . This code can be (but it does not have to be) different in each case. The codes of the particular regions in groups (or types) are the following:

\begin{tabular}{|c|c|c|c|c|c|c|c|}
\hline \multicolumn{4}{|c|}{ GROUP A } & \multicolumn{4}{|c|}{ GROUP D } \\
\hline Nukuoro 19 & 3355 & 2111 & 2112 & Phuket & 4522 & 5355 & 5555 \\
\hline Nukuoro 20 & 4155 & 2221 & 2222 & Samui & 4454 & 5455 & 5355 \\
\hline Ebon & 3345 & 2124 & 2113 & Thira & 4345 & 4544 & 5355 \\
\hline Mili & 3255 & 3134 & 2213 & Cerdanya & 2354 & 5455 & 5455 \\
\hline Shimshal & 3255 & 2131 & 1212 & Gabès & 5454 & 5253 & 5455 \\
\hline Jap 19 & 3345 & 2121 & 4223 & & & & \\
\hline \multicolumn{4}{|c|}{ GROUP B } & \multicolumn{4}{|c|}{ GROUP E } \\
\hline Praslin & 4435 & 4354 & 4345 & Rodrigues & 4444 & 3134 & 3345 \\
\hline Zaafrane & 4355 & 3343 & 1231 & Jap 20 & 3442 & 2235 & 5335 \\
\hline Tamerza & 5454 & 4343 & 1343 & Farafra & 5554 & 3233 & 2324 \\
\hline Cilaos & 4455 & 4254 & 2355 & Astipalea & 1255 & 4433 & 1335 \\
\hline Folegandros & 2355 & 4444 & 2354 & Silhouette & 1255 & 3234 & 3234 \\
\hline (Tao) & 2255 & 2523 & 1124 & Mafate & 1155 & 2332 & 3333 \\
\hline \multicolumn{4}{|c|}{ GROUP C } & Pha-Ngan & 3255 & 2443 & 2345 \\
\hline Lanta & 4244 & 2223 & 4314 & Desroches & 1455 & 4444 & 1222 \\
\hline Chang & 2355 & 3322 & 2124 & \multicolumn{4}{|c|}{ GROUP $\mathrm{F}$} \\
\hline Amorgos & 1455 & 3453 & 3355 & Samet & 3454 & 4543 & 4222 \\
\hline \multirow[t]{3}{*}{ Douz } & 5454 & 3243 & 1345 & Phi Phi & 2444 & 4544 & 1335 \\
\hline & & & & Panyi & 5355 & 5145 & 1133 \\
\hline & & & & Causse Noir & 1345 & 4534 & 4355 \\
\hline
\end{tabular}

Comparing the various codes, it is possible to state that:

1. The more isolated a region is, the less transformed (innova-tively, dynamically, efficiently) are the characteristics of its community. As the region "opens" up, its community becomes more susceptible to change.

Such a deduction is not very surprising. Intuitively we knew that this was a natural process. However the fact that we were able to measure this dependency is pleasing and makes our methods more trustworthy. 
2. The characteristics of communities from regions with a similar degree of isolation are similar. The greatest similarity occurs in regions with the highest level of isolation and those that are considered to be most "open". The characteristics of communities from regions that are "opening up" to the outside world are showing a greater variety. This can be the result of the search for various methods of development by communities from isolated regions. However, the starting point (isolation) and the goal ("openness") become factors assimilating social functions.

3. Isolation most probably has the greatest influence on how communities living in isolated regions manage their affairs. A great similarity between the values of characteristics of the communities in all the types of regions serves as proof of this. Other characteristics (social and spatial) seem to be modified to a great degree by other factors, since the range of distance values between the different types is large. The greatest differentiation in spatial organisation is shown by regions from groups with an average spatial isolation.

4. On the basis of the study of the degree of isolation of 33 regions and the communities inhabiting them, it can be assumed that isolation causes similar social processes on islands and on isolated mountainous regions, whilst the communities of oases, despite similar isolation, function in a slightly different manner. Thus, as far as valleys and plateaus can be considered as "islands" situated on continents, oases - contrary to expectation - cannot be considered as such.

\section{REFERENCES}

B onniol J.-L., 1987, Micro-insularité et particularisme: approche comparé à partir de cas antillais et seychellois, [in:] Îles tropicales: insularité, "insularisme", CRET, Université de Bordeaux, 67-86.

Dou menge F., 1984, Unité et diversité des caractères naturels des îles tropicales, [in:] Nature et hommes dans les iles tropicales, CEGET-CRET, Bordeaux, 9-24.

Doumenge F., 1987, Quelques contraintes du milieu insulaire, [in:] Iles tropicales: insularité, "insularisme", CRET, Université de Bordeaux, 9-16.

Jędrusik M, 1997, Mikronezja, [in:] Wyspy cieptych mórz [Islands of the warm seas], University of Warsaw, 19-43.

Kubary J.S., 1882, Wyspy Nukuoro (z podróży po Oceanie Wielkim) [The islands of Nukuoro (from a voyage on the Pacific Ocean)], Ateneum, 3, 94-121, 263- 292.

Kubary J.S., 1882, Z podrózy po Mikronezyi. Wyspy Ebon. Notaty zebrane w latach $1870-1880$ [Voyages on Micronesia. The islands of Ebon. Notes collected from 1870 to 1880], Wędrowiec, t. 39, no.1006-1010, pp. 234-236,241-243, 265-266, 273-276, 289-291, 310-312, 328-330.

Kub a r y J.S., Z podróży po Mikronezyi. Notaty zebrane w latach $1870-1880$ przez Jana Stanisława Kubarego. Wyspa Jap [Voyages on Micronesia. Notes collected from 1870 to 1880 ) by Jan Stanisław Kubary. The Island of Jap], manuscript in the Polish Ethnographic Archive in Wrocław, inv. no. 314.

Las s erre G., 1987, Le géographe et les îles, [in:] Îles tropicales: insularité "insularisme", CRET, Université de Bordeaux, 1-6.

Le Causse Noir. L'eau, la terre et la femme, 1987, Université Montpellier III, Université de Varsovie, Montpellier. 
Mac Arthur R.H., Wilson E.O., 1967, The Theory of Island Biogeography, Princeton University Press, Princeton (N.J.).

Plit F., 1993, Wprowadzenie (Introduction), [in:] Farafra - wstępne wyniki badań [Farafra - preliminary results of studies], Working Paper no 12, Institute of Developing Countries, Faculty of Geography and Regional Studies, University of Warsaw, (mimeo).

S a us sol A., 1987, Peut-on parler de créolité en Nouvelle- Caledonie? Reflexions autour d'une identité insulaire, [in:] Îles tropicales: insularité, "insularisme", CRET, Université de Bordeaux, 157-164.

Skotnicki M., 1993, Uzytkowanie ziemi [in:] Farafra - wstępne wyniki badań [The land use [in:] Farafra - preliminary results of studies], Working Paper no 12, Institute of Developing Countries, Faculty of Geography and Regional Studies, University of Warsaw, (mimeo). 
